\title{
CONCEPTUALIZATION OF TEACHER BURNOUT AND ONLINE BURNOUT PREVENTION AMONG HUNGARIAN TEACHERS
}

\author{
Szilvia Horváth ${ }^{1}$, \& Katalin N. Kollár ${ }^{2}$ \\ ${ }^{1}$ Doctoral School of Psychology, Eötvös Loránd University Faculty of Education and Psychology \\ (Hungary) \\ ${ }^{2}$ Department of Counselling and School Psychology, Eötvös Loránd University Faculty of Education and \\ Psychology (Hungary)
}

\begin{abstract}
In our study, we were testing an online burnout prevention programme among Hungarian teachers between 2016-2019, focusing on the background factors of the intervention effect size. Firstly, we conceptualized teacher burnout factors, and after exploratory and confirmatory factor analysis on the incoming sample $(\mathrm{N}=224)$, structure equation model has been built up which relate to work-stressors like effort-reward imbalance and over-commitment, burnout factors, perceived stress, general self-efficacy and depression. Secondly, by testing the stress-management intervention on a cumulated sample $(\mathrm{N}=37)$ which based on a mini randomized control trial and a quasi-experiment sample data, the intervention effect size has been evaluated, linear regression and structure equation modelling was used to explore the intervention' predictor and moderator variables.

Results of the conceptualization $(\mathrm{N}=224)$ show work stressors alone do not lead to burnout factors. Perceived stress is mediator from effort-reward imbalance to burnout factors. General self-efficacy modifies negative impact of perceived stress on personal accomplishment and directly depersonalization. Coping mechanism of depersonalization and personal accomplishment strengthens one-dimensional approach of burnout.

Results of the intervention evaluation show that significant high improvement can be achieved related to the emotional exhaustion ( $\mathrm{N}=37 d=0.89, \mathrm{p}<.01)$.

For prevention, all kind of stress-management techniques, improving teachers' perceptions of work success are presumable. In order to reach higher involvement of the participants for further research cultural adaptation is needed.
\end{abstract}

Keywords: Burnout, teacher burnout, internet intervention, structure equation model.

\section{Introduction}

Several studies have shown that teachers have high risk within the population regarding work-related burnout and chronic stress disease. Factually it means that $60-70 \%$ of the European teachers suffer from chronic stress disease, and $30 \%$ of them have burnout syndrome. In Hungary, $89 \%$ of the Hungarian teachers report about being overworked and work-related stress, $60 \%$ of them feel that they don't have control over their own responsibilities (Lubinszki, 2013).

International research, which focuses on the risk factors of teacher burnout, also investigates its organisational and individual aspect. Regarding the last one, they found that age, gender, marital status and education level as risk factors of teacher burnout. At organisational level role conflicts, effort-reward imbalances and perceived work stressors correlate mainly with the phenomenon of teacher burnout (Carod \& Artal, 2013). Hungarian studies also confirm the individual risk factors in a coherent way with age: related burnout primarily a threat to younger (24- to 40-year-old) teachers, and among them, the rate of the carrier leaving is relatively high (30-40\%) (Gáspár et al., 2006).

Social protection, recognition, the strength of safety nets and co-workers, management support, can be considered as protective factors to avoid burnout. Many studies have proven that the lack of management/leadership support increases the burnout risk to more than $50 \%$, and the effects are reversed. The most important protective factor is any rewarding from the leadership regardless of the fact that contains neither financial or material allowance. 
A previous study among Hungarian teachers from Salavecz et al. (2006a) focused on work stress and self-efficacy as determiners of teachers' mental health. The purpose of their study was twofold: firstly, to analyse the association between job stress and mental health among teachers, secondly to clarify the role of two individual factors, self-efficacy and over-commitment in the development regarding mental health state. Based on their results, it can be assessed that the personal characteristics and job stress influence differ due to the various mental health variables. Effort-reward imbalance is an important determiner of teachers' psychological health. Over-commitment and self-efficacy proved to be predictors of both burnout syndrome and vital exhaustion, while none of these individual factors proved to be determiners of depressive symptomatology. Authors point out that in designing intervention programmes which are aimed to preserve mental health that is worth to take into consideration such kind of studies focusing on the personal characteristics and also work-stress influences.

An important milestone in literature is the one-dimensional burnout approach (Demerouti, 2005; Shirom, Melamed, 2006; Toppi-nen-Tanner, 2011), which critics of the Maslach three factorial burnout model raise attention that depersonalisation should be considered as coping strategy and reduced self-efficacy is the long-term consequence of the existing stress.

Several studies reflect on the therapy and prevention of occupational burnout syndrome (e.g. van Dick and Wagner, 2001; Ahola et al., 2017; Salavecz, 2006; Kiss et al., 2018; Flook et al., 2013; Zolnierczyk-Zreda, 2005; Kemeny et al., 2012), which direction can be organisational and also self-focused. Regarding teacher burnout, the situation could be improved if the individual teacher was better trained to deal with the stressful aspects of teaching. There are programmes developed specifically for enhancing teachers' self-efficacy (Brockmeyer, 1997) or in a similar manner training to improve coping strategies could also be helpful (Tyler, 1998) as it also seems useful to improve interactions between colleagues to enhance workplace support.

Due to the COVID-19 situation and home-office, Internet-based prevention programs in the frame of occupational e-mental health have come to fore, as special forms of intervention for mental hygiene and reducing psychosocial stress at work. As Phillips et al. (2019) state, the question of the effectiveness of e-mental health interventions, in general, has been addressed in several systematic reviews and meta-analyses. E-mental health interventions were found to be effective in reducing stress in a general population with small to moderate effects. Heber et al. (2013) reported a small effect size for stress symptoms (Cohen's d=0.43), Jayawardene et al. (2017) in their meta-analysis of the effectiveness of online mindfulness interventions found a small treatment effect $(g=0.42)$, Spijkerman et al. (2016) found a moderate effect size $(\mathrm{g}=0.51)$. While concerning the effectiveness results are still conflicting, it is important to identify factors that determine the effect of treatment outcome. Most of the study which explored the characteristics of the participants used online cognitive behavioural therapy (Ebert, 2013) and just one study (Junge et al., 2014) examined which employees might or might not benefit from internet-based problem-solving training as a specific kind of treatment and delivery.

\section{Methods}

In our trial, both treatment forms were used: at the first part of the intervention the participants took part in a regeneration training (Get.On: Fit im Stress $\left.{ }^{\circledR}\right)$, which was followed by an internet-based problem-solving training. The participants were recruited on social media and by the recommendation of school psychologists, who are members of the National School Psychologist Methodological Base (Országos Iskolapszichológiai Módszertani Bázis). Because of the length of the training and taking into account the drop-out, we will only make findings of the sample in connection with the effectiveness of the regeneration training.

Period of data collection was 09.01.2016-04.01.2017 (Study 1) and 11.01.2018-05.01.2019 (Study 2) and the registered number of the participants was $\mathrm{N}=187$ (Study 1), $\mathrm{N}=40$ (Study 2). For intervention evaluation, a cumulated sample from the two studies was used, which consists of 37 participants (treatment sample $\mathrm{N}=17$, control sample $\mathrm{N}=20$ ). Statistical analysis has been based on the assessment of the following factors and variables: burnout (Maslach Burnout Inventory, 1981), general self-efficacy (Schwarzer, 1995), perceived stress (Cohen, 1983), effort-reward imbalance questionnaire (Siegrist, 1996), depression (Beck, 1961).

\section{Results}

Regarding the intervention, significant high improvement can be achieved related to the emotional exhaustion $(\mathrm{d}=0.89, \mathrm{p}<.01)$, small improvement can be detected in perceived stress $(\mathrm{d}=0.33$, $\mathrm{p}<.05$ ). On the base of our income data, exploratory and confirmatory factor analysis has shown that emotional exhaustion as the main factor of burnout belongs to the 'stress' variables (like perceived stress, 
effort-reward imbalance, over-commitment and depression) and beside general-efficacy, the two other burnout factors as depersonalisation, personal accomplishment belong to the 'coping' factors $\mathrm{N}=224$, $\chi^{2}=4.1, \mathrm{p}<.01, \mathrm{CFI}=.91$, rmsea $=.11$, all variables are significant in the model).

The conceptualisation of teacher burnout with a complex free pathway structure equation model on the income data highlighted that perceived stress is mediator from effort-reward imbalance to burnout factors, general self-efficacy modifies the negative impact of perceived stress on personal accomplishment and directly depersonalisation $\left(\mathrm{N}=224, \chi^{2}=1.19, \mathrm{p}=0.25, \mathrm{CFI}=.99\right.$, rmsea $=.03$, all variables are significant).

A variable that predicts outcome regardless of the treatment intervention is called a predictor; a variable that identifies for whom and under what conditions treatments have different effects called moderator (Kraemer et al., 2002). Linear regression and SEM modelling helped to point out predictor and moderator variables of the intervention related to changes in emotional exhaustion: the main predictor in treatment and control sample is incoming emotional exhaustion, moderator variable is depersonalisation. Results confirmed that higher the incoming depersonalisation of the participants in the treatment group is higher improvement can be detected by completing the training. In the control group, such an inverse relationship cannot be detected.

\section{Discussion}

In sum, results verify the one-dimensional burnout approach in the literature in the sense that depersonalisation and personal accomplishment can be considered as a coping mechanism of burnout and emotional exhaustion is the main factor of burnout, on which stress affects. Depersonalisation is a moderator also in agreement with the literature (Junge et al., 2014, Ebert et al., 2014)), when we consider that depersonalisation has significant positive correlation $(\mathrm{r}=.48, \mathrm{p}<.01)$ with depression severity, which is also a significant moderator of emotional exhaustion at internet-based problem-solving training as well.

Nevertheless, there are some limitations of our study: a small sample size of intervention evaluation reduces the validity of the statements as well as biases that occur during data collection. However, the promising results call attention to the fact that there is room for the use of online burnout prevention programs among Hungarian teachers and to be more effective, the cultural adaptation of interventions is necessary.

\section{References}

Ahola, K., Toppinen-Tanner, S., Seppänen J. (2017). Interventions to alleviate burnout symptoms and to support return to work among employees with burnout: Systematic review and meta-analysis. Burnout research, 4, 1-11.

Beck, A.T., Ward, C.H. (1961). An inventory for measuring depression. Arch Gen Psychiat, 4, 561-571.

Brockmeyer, R. (1997). Selbstwirksame Schulen. Oberhausen: Laufen.

Cohen, Sh., Kamarck, T., Mermelstein, R. (1983). A Global Measure of Perceived Stress, Journal of Healthand Social Behavior, 24, 385-3.

Demerouti, E., Verbeke, W. J., Bakker, A. B. (2005). Exploring the relationship between a multidimensional and multifaceted burnout concept and self-rated performance. Journal of management, 31(2), 186-209.

Ebert, D., Gollwitzer, M., Riper, H., Cuijpers, P., Baumeister, H., Berking, M. (2013) For whom does it work? moderators of outcome on the effect of a transdiagnostic internet-based maintenance treatment after inpatient psychotherapy: randomized controlled trial. J Med Internet Res., 15, 191.

Ebert, D., Lehr, D., Boß, L., Riper, H., Cuijpers, P., Andersson, G., Thiart, H., Heber, E., Berking, M. (2014). Efficacy of an Internet-based problem-solving training for teachers: Results of a randomized controlled trial, Scandinavian journal of work, environment \& health

Flook, L., Goldberg, S. B., Pinger, L., Bonus, K., \& Davidson, R. J. (2013). Mindfulness for teachers: A pilot study to assess effects on stress, burnout, and teaching efficacy. Mind, Brain, and Education, 7 (3), 182-195.

Gáspár, M. (2006). A személyiség belsö feltételeinek és stabilitásának alakulása a pályaszocializáció függvényében. Budapest: OTKA pályázat

Heber, E., Ebert, D., Lehr, D., Nobis, S., Berking, M., Riper, H. (2013). Efficacy and cost-effectiveness of a web-based and mobile stress-management intervention for employees: design of a randomized controlled trial. BMC Public Health, 13, 655. 
Jayawardene, W., Lohrmann, D., Erbe, R., Torabi, M. (2016). Effects of preventive online mindfulness interventions on stress and mindfulness: A meta-analysis of randomized controlled trials. Preventive Medicine Reports, 5, 150-159.

Junge, M., Lehr, D., Bockting, C., Berking, M., Riper, H., Cuijpers, P., Ebert, D. (2014). For whom are Internet-based Occupational Mental Health Interventions effective? Moderators of Internet-based Problem-Solving Training Outcome, Internet Interventions

Kemeny, M. E., Foltz, C., Cavanagh, J. F., Cullen, M., Giese-Davis, J., Jennings, P., Rosenberg, E. L., Gillath, O., Shaver, P. R., Wallace, B. A., \& Ekman, P. (2012). Contemplative/emotion training reduces negative emotional behavior and promotes prosocial responses. Emotion, 12 (2), 338-350.

Kiss, T., Polonyi, T., Imrek, M. (2018). Munkahelyi stressz és egészség. A burnout szindróma a 21. Században - Kutatás, mérés, elmélet és terápia, Alkalmazott Pszichológia, 18(2), 75-103.

Kraemer, H.C., Wilson, G.T., Fairburn, C.G., Agras, W.S. (2002). Mediators and moderators of treatment effects in randomized clinical trials. Arch Gen Psychiatry, 59, 877-83.

Lubinszki, M. (2013). A kiégés komplex értelmezése és prevenciós lehetőségei a pedagóguspályán. In Jubileumkötet a Miskolci Egyetem Bölcsészettudományi Kar 20 éves jubileumára (pp. 263-276.). Miskolc: Miskolci Egyetem.

Maslach, C., Leiter, M.P. (2016). Understanding burnout experience: recent research and its implications for psychiatry. World Psychiatry, 15(2), 103-111.

Phillips, E.A, Gordeev, V.S, Schreyögg J. (2019) Effectiveness of occupational e-mental health interventions: a systematic review and meta-analysis of randomized controlled trials. Scand J Work Environ Health, 45(6), 560-576.

Salavecz, Gy., Neculai, K., Jakab, E. (2006). A munkahelyi stressz és az énhatékonyság szerepe a pedagógusok mentális egészségének alakulásában. Mentálhigiéné és Pszichoszomatika, 7, 96-109.

Schwarzer, R., Jerusalem, M. (1995). Generalized Self-Efficacy scale. In Weinman, J., Wright, S., Johnston, M. (Eds.), Measures in health psychology: A user's portfolio. Causal and control beliefs (pp. 35-37). NFER-NELSON, Windsor, UK

Shirom, A., Melamed, S. (2006). A comparison of the construct validity of two burnout measures in two groups of professionals. International Journal of Stress Management, 13(2), 176-200.

Siegrist, J. (1996). Adverse health effects of high-effort/low-reward conditions. Journal of Occupational Health Psychology, 1, 27-41.

Spijkerman, M.P., Pots, W.T., Bohlmeijer, E.T. (2016) Effectiveness of online mindfulness-based interventions in improving mental health: A review and meta-analysis of randomised controlled trials. Clin Psychol Rev., 45, 102-14.

Toppinen-Tanner, S. (2011). Process of burnout: Structure, antecedents and consequences. People and Work Research Reports, 93, Finnish Institute of Occupational Health, Helsinki.

Tyler, M. (1998). Stress-management training for teachers: A practical guide. In J. Dunham \& V. Varma (Eds.), Stress in teachers. Past, present and future (pp. 160-182). London: Whurr.

Van Dick, R., Wagner, U. (2001). Stress and strain in teaching: A structural equation approach. British Journal of Educational Psychology, 71, 243-259.

Zolnierczyk-Zreda, D. (2005). An intervention to reduce work-related burnout in teachers. Journal of Occupational Safety and Ergonomics, 11, 423-430. 